\title{
Immunohistochemical study of cutaneous neuritis in positive lepromin reactions
}

\author{
LUCIO BAKOS* \& SEBASTIAN B. LUCAS $\dagger$ \\ * Dermatology Service, Hospital de Clinicas, Federal University of \\ Rio Grande do Sul, Ramiro Barcelos 2350, Porto Alegre, Brazil; \\ and $†$ Electron Microscopy \& Histopathology Unit, London School \\ of Hygiene and Tropical Medicine, London WC1E 7 HT
}

Accepted for publication 6 June 1995

Summary Sixty skin biopsies taken from positive tuberculoid and borderlinetuberculoid late lepromin reaction were studied using histological techniques. The distribution of mycobacterial antigen and nerves was demonstrated using immunochemical methods.

A total of 557 nerve bundles was observed in 51 biopsies; 9 were devoid of nerves in the sections examined; 475 nerve bundles showed some relationship to the inflammatory infiltrate $(85 \%)$; perineuritis being seen in $144(30 \%)$ and endoneuritis in $5(0.9 \%)$.

Mycobacterial antigens inside the granuloma were detected in 59 of the 60 biopsies (98\%). Only one specimen, showing a strong tuberculoid reaction, failed to show these antigens. On the contrary, mycobacterial antigen was absent in almost all nerves. Small deposits were detected in the perineurium of one nerve with perineuritis, and inside a Schwann cell of another, the latter belonging to a previously multibacillary patient.

The neurotropic tendency of the granuloma does not seem to be stimulated by the presence of mycobacterial antigens inside the nerves, as normally these antigens do not penetrate them. The hypothesis of some antigenic fraction of the neural tissue which cross-reacts with Mycobacterium leprae antigens, thus eliciting a perineural or near-perineural inflammatory reaction is put forward, but needs further investigation.

\section{Introduction}

During the last 70 years, the lepromin test has been widely used throughout the world to assess the immune status of leprosy patients and their contacts. The type of lepromin developed by Mitsuda in 1919, ${ }^{1}$ is still used today.

The positive Mitsuda test, or late or delayed lepromin reaction, consists of a nodular induration of the skin, of varied size, at the site of the dermal inoculation of the 
substance, reaching its maximum size between the third and fourth weeks after the injection, slowly involuting afterwards, sometimes leaving an atrophic scar. Ulceration can occur in strongly positive reactions. Its presence is regarded as an indicator of resistance of the host to $M$. leprae infection, ${ }^{2-5}$ being the result of a delayed hypersensitivity reaction to the injected antigen. ${ }^{6-8}$

The inoculated antigens can be of human origin, obtained both by the Mitsuda or by the Dharmendra method from human lepromata, or of animal origin, obtained from armadillos experimentally infected with $M$. leprae.

Histologically, the classical positive Mitsuda reaction consists of a dense grouping of epithelioid cells, with multinucleated giant cells and lymphocytes, thus forming a typical tuberculoid structure, similar to that encountered in TT or BT cases of leprosy. The size and type of cells in the granuloma can be variable according to the spectral concept of leprosy. ${ }^{6,14,18}$

The histopathology of the lepromin reaction has been extensively studied. ${ }^{9,11,13,16}$ Some authors note the preference for the inflammatory cells to be arranged around blood vessels and skin appendages, without referring specifically to nerves. ${ }^{7,10}$ Nerve involvement in lepromin reaction received specific attention in five papers, the authors of these stressing the frequency of neural involvement in the biopsies. ${ }^{7,12,15,19,20}$

Mistry et $a l .{ }^{20}$ have raised the question of why infiltration should be seen specifically around dermal nerves. Desikan et al. ${ }^{7}$ suggest that nerve tissue could be in some way associated with the immunological process of the lepromin reaction, possibly having some role in delayed hypersensitivity reactions, particularly in view of the special predilection of $M$. leprae for nerves. ${ }^{21}$ Serial $^{15}$ states that neuritis in lepromin reactions is 'undoubtedly' caused by very specific 'endotoxic' substances released by M. leprae, with an affinity for the peripheral sensory nerves.

Cutaneous nerves can be more easily identified in sections by using immunoperoxidase technique with S-100 protein as a Schwann cell marker, as the inflammatory infiltrate in leprosy can make this identification difficult in routine stains. ${ }^{22} \mathrm{M}$. leprae antigens can also be clearly demonstrated in histological sections by the peroxidaseantiperoxidase (PAP) immunoenzyme technique using rabbit anti-Mycobacterium bovis (BCG) as the primary antibody, as most of $M$. leprae antigens cross-react with BCG. $^{23,24}$

In this report we quantify and classify cutaneous nerve damage in positive Mitsuda tests and locate the antigen in the tissue, in an attempt to explain the mechanism of the neural involvement frequently observed in the histology of granulomatous lepromin tests.

\section{Materials and methods}

Sixty positive lepromin test human biopsies were studied. In 50 cases, human-derived lepromin (lepromin H) and in 10, armadillo-derived (lepromin A) had been used. Fivemicron-thick sections were cut, left to dry in an oven at $56^{\circ} \mathrm{C}$, dewaxed in xylene, passed through graded alcohols and into water. Haematoxylin and eosin, Ziehl-Nielssen and Wade-Fite stains were used for classification of the type of granuloma ${ }^{18}$ and for demonstration of $M$. leprae at the site of inoculation. 
IMMUNOPEROXIDASE METHODS

The Avidine-Biotin-Complex (ABC) method of immunoperoxidase using anti-S-100 protein antibody was used in the study as a marker for Schwann cells to detect nerves in sections, according to the method of Hsu et al. ${ }^{34}$ Normal goat serum at 1:2000 was used as a negative control, and normal nerve sections stained for S-100 protein as positive controls. To detect mycobacterial antigens in the tissues, a peroxidase antiperoxidase (PAP) method was used, following the method of Sternberger et al. ${ }^{25}$ using antiBCG antibodies.

$\mathrm{UCHL}_{1}$ ( $\mathrm{T}$ cells) and $\mathrm{CD}_{45}$ (leukocyte common antigen) methods were used to confirm penetration of inflammatory cells into the nerves, in four selected cases of endoneuritis.

\section{CLASSIFICATION OF NERVES}

Nerves were classified according to their histological alterations and location in the granuloma.

Perineuritis was considered present if inflammatory cells penetrated the perineurium or were present in perineural spaces (Figure 1); endoneuritis, only if inflammatory cells were present inside the nerve, at times with nerve destruction (Figure 2 and 3). Nerves were classified as related to granuloma, when surrounded or tangentially touched by the granuloma (Figure 4), and normal distant nerves, when distant and not related to the granuloma.

The size and type of the granulomatous reaction, the number of giant cells, the absence or presence of lymphocytes around or inside the granuloma, as well as the presence of caseating necrosis, or ulceration, were the parameters used together to classify the histological lepromin response as tuberculoid or as one of the variety of positive borderline cases. ${ }^{14,18}$

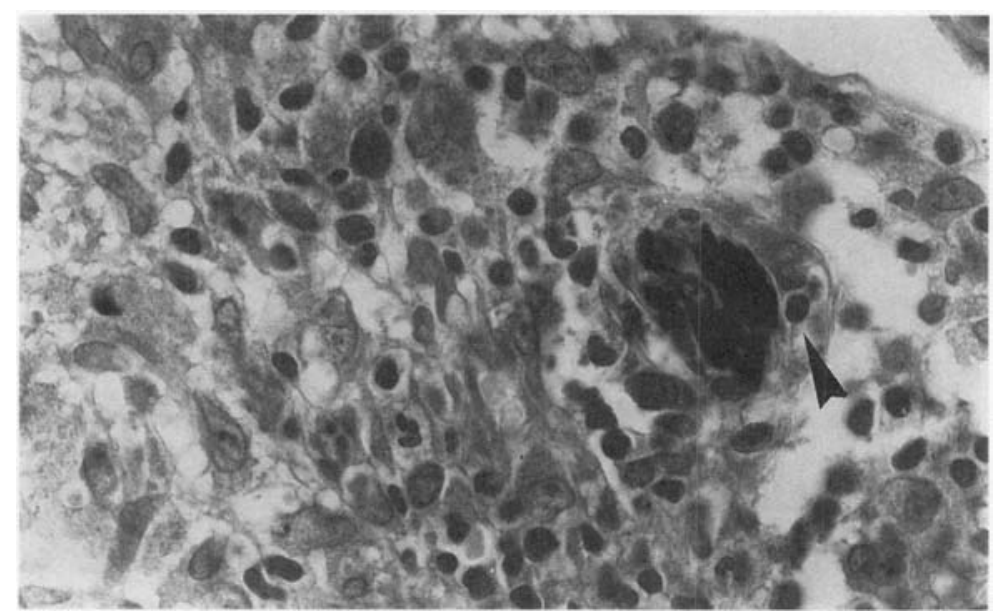

Figure 1. Perineuritis. Inflammatory cells in perineural spaces (arrow) $(\mathrm{S}-100 \times 1000)$. 


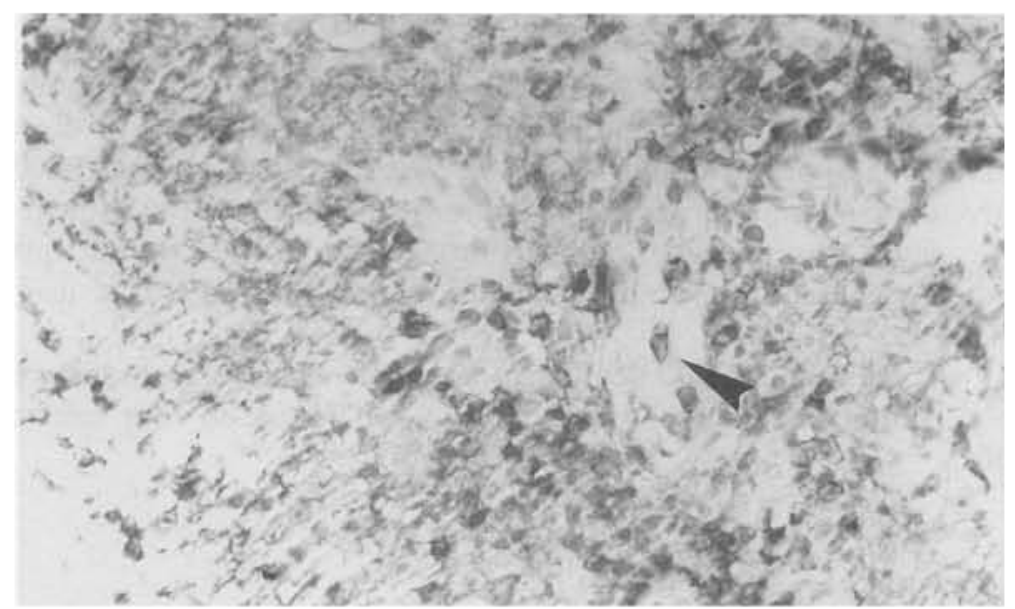

Figure 2. Endoneuritis. $\mathrm{CD}_{45}+$ inflammatory cells inside the nerve (large arrow). Small arrows delimitate nerves. $\left(\mathrm{CD}_{45} \times 400\right)$.

The Bacterial Index (BI) of Ridley ${ }^{26}$ was used to quantify the number of acid-fast bacilli (AFB) present in Wade-Fite stains. The quantity of antigen present in the tissues, detected by the antiBCG method was measured on a scale graded from 0 to $3+$.

\section{Results}

Dermal nerves were present in 51 of the 60 specimens $(85 \%)$; 557 nerves were identified

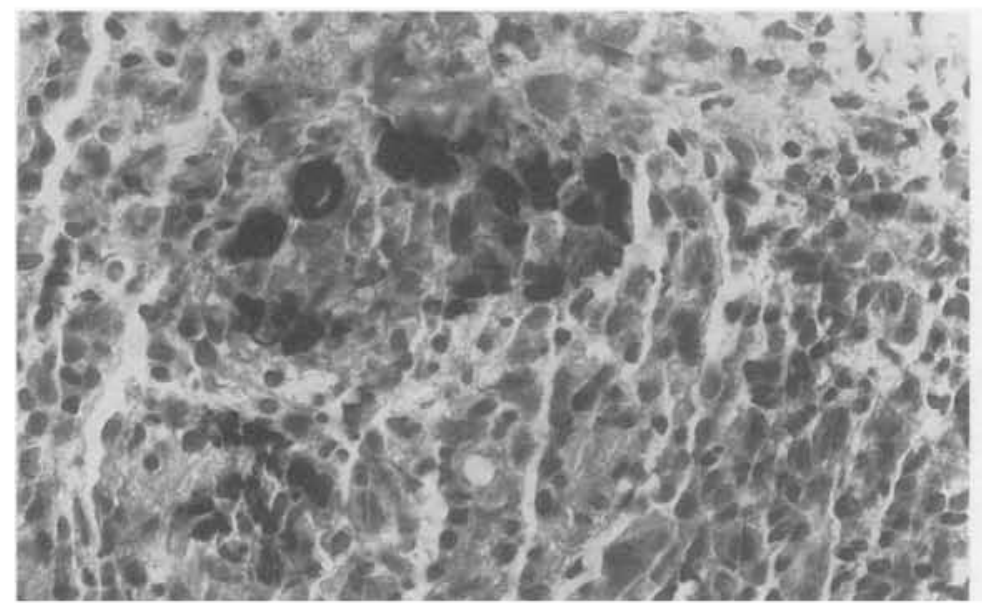

Figure 3. Endoneuritis with nerve destruction. S-100-positive Schwann cells (black granules) delimitate the nerve bundle disrupted by inflammatory cells. $(\mathrm{S}-100 \times 400)$. 


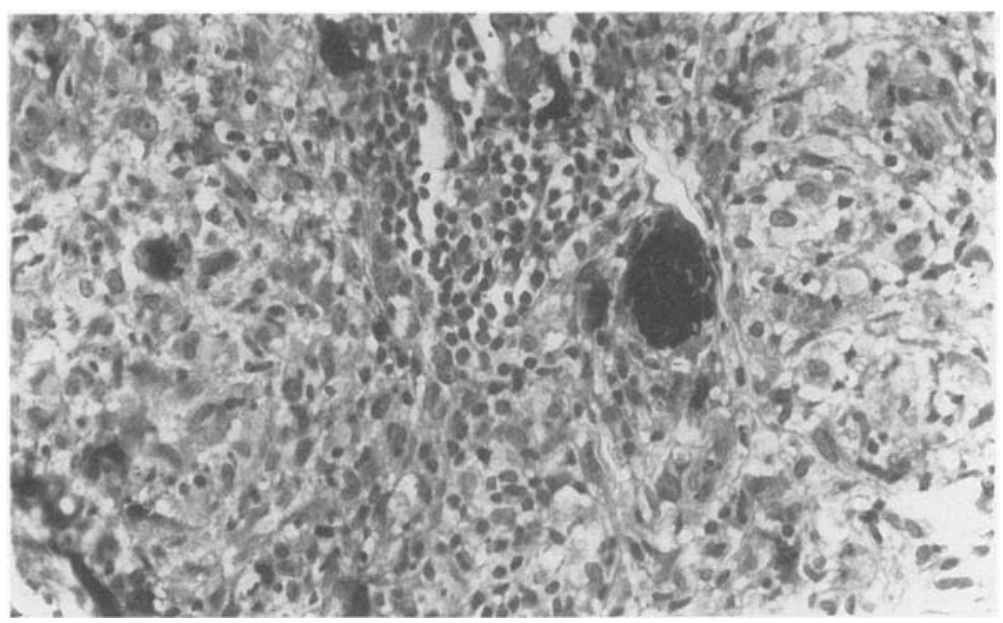

Figure 4. Dermal granuloma surrounding an uninvolved nerve (arrow) $(\mathrm{S}-100 \times 400)$.

in the sections. Of these, $169(30 \%)$ showed perineuritis and only $5(0.9 \%)$ presented endoneuritis; 86 unaffected nerves were found inside the granulomas $(15 \%)$ and 161 $(29 \%)$ at the periphery of the granulomas; 54 nerves $(10 \%)$, although related to the granulomas, were difficult to classify due to artifacts or to blurring of their perineural areas. Considering together all types of nerves, affected or related to the granulomas, the total count was $475(85 \%)$. Normal distant nerves not related to the granulomatous reaction accounted for only $82(15 \%)$ of the total (Table 1$)$.

In perineuritis and endoneuritis the penetrating cells were basically lymphocytes $\left(\mathrm{UCHL}_{1}+\right.$ and $\mathrm{CD}_{45}+$ ). No granulomas were observed inside the nerves.

Acid-fast bacilli (AFB) were identified in $53 \%$ of the biopsies. When present, the granular or fragmented bacilli were found isolated or in small clumps inside the macrophages or more inf requently, isolated between collagen bundles. They formed groups or large clumps in areas of the necrosis and even more intensely in those of suppuration. No AFB were found in dermal nerves.

AntiBCG stain was very sensitive to detect mycobacterial antigen, being positive in $98 \%$ of the biopsies, and negative in only one case, a strongly positive lepromin reaction of a tuberculoid patient. The antigen could be detected within macrophages, in multinucleated giant cells, in necrotic areas and even between collagen bundles, with varied intensity. The antigen reached the neighbouring area of the nerves, without normally penetrating the perineural areas. Five hundred and fifty-five nerves $(97 \%)$ did not show any mycobacterial antigen. Only two nerves with perineuritis showed $1+$ deposit of antigen. In one nerve the antigen was located in the inflamed perineurium. In the other, obtained from a BL case having undergone long-term treatment, a small deposit of BCG-positive material was present within a Schwann cell (Figure 5).

In all cases of endoneuritis we were not able to demonstrate any antigen inside the nerves.

Sometimes nerves were difficult to identify in the PAP/BCG sections, making impossible the precise counting and the distance between them and the antigen deposits. Very frequently, however, especially in $1+$ and in some $2+$ deposits, we could see nerves 
Table 1. Type of nerve involvement and its position regarding the granuloma. Only $15 \%$ of all nerves were unaffected and not related to the granuloma.

\section{NERVE INVOLVEMENT IN MITSUDA REACTION TYPE OF NERVE INVOLVEMENT}

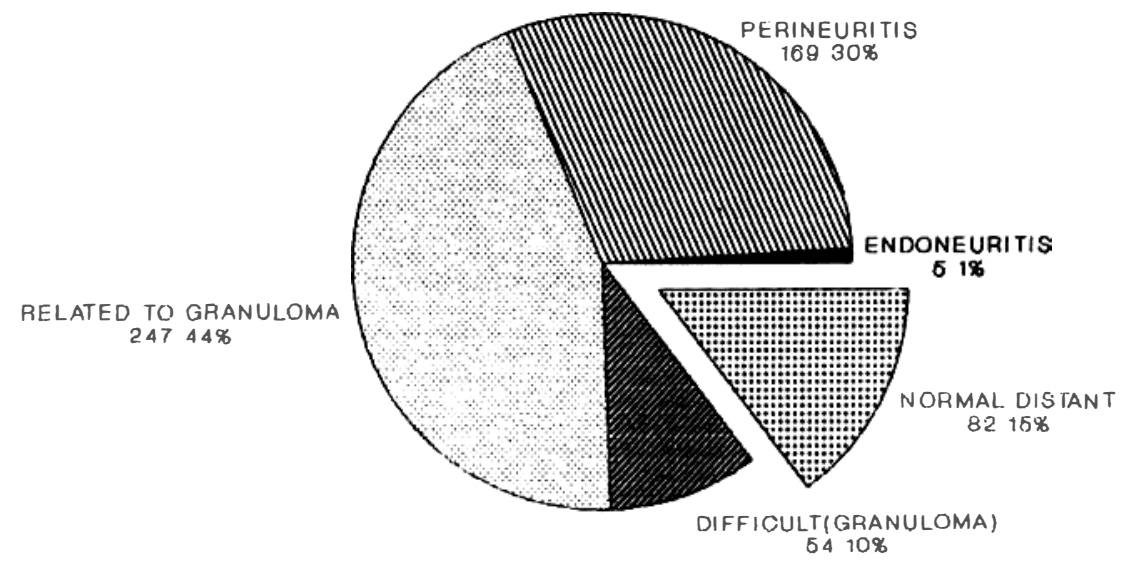

\section{$n=557$}

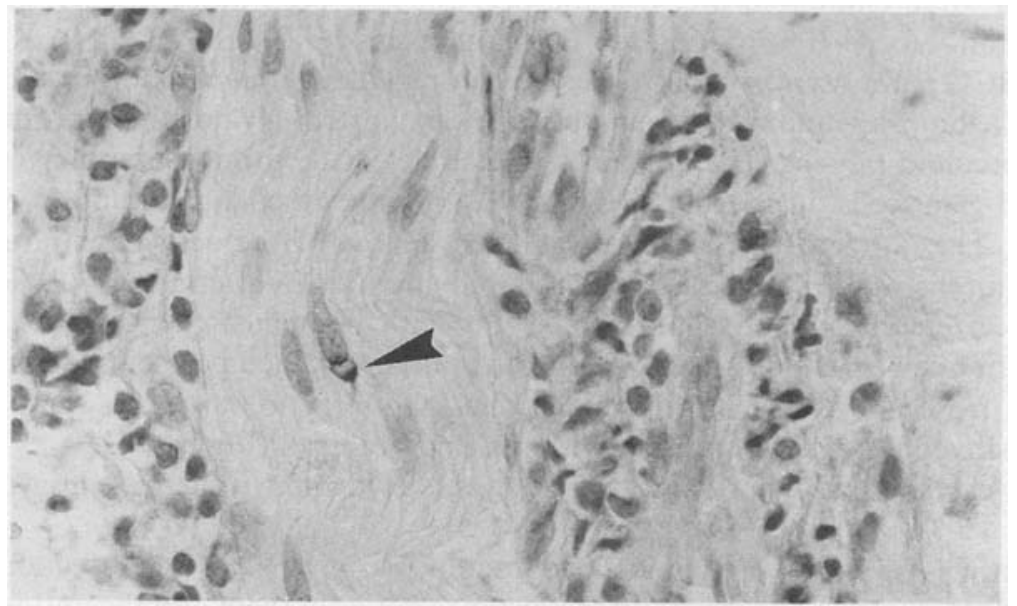

Figure 5. BCG-positive material within a Schwann cell (arrow) $(\mathrm{BCG} \times 1000)$. 


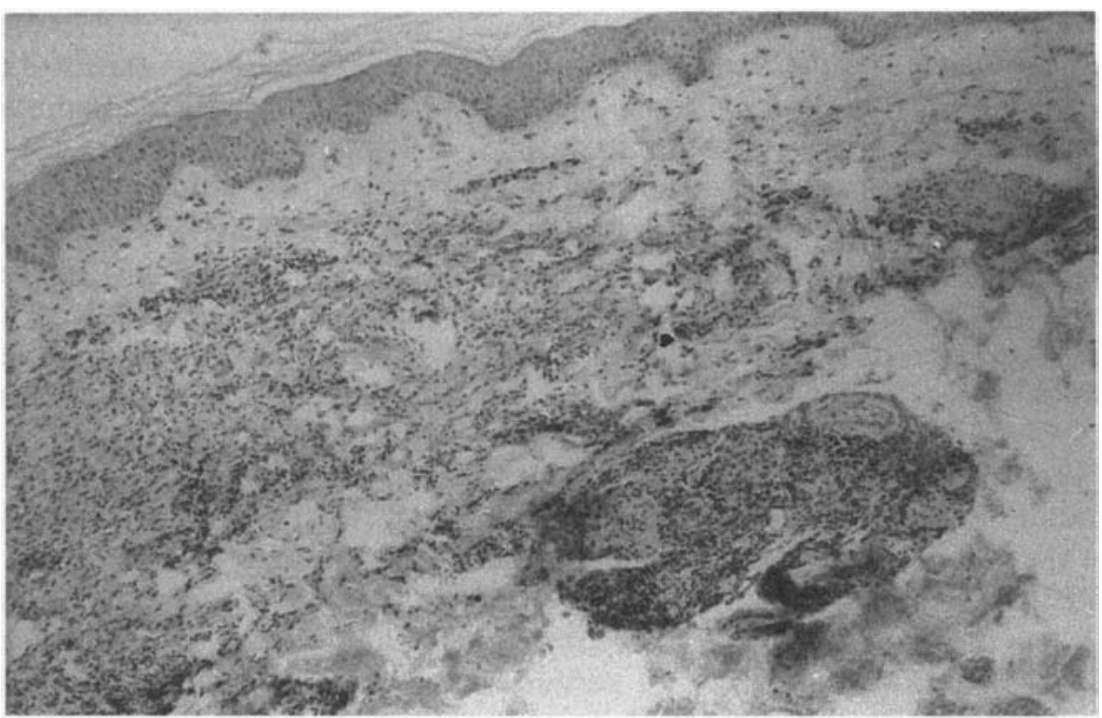

Figure 6. Low power micrograph of a lepromin reaction showing preference of the inflammatory infiltrate to concentrate around nerve bundles and blood vessels (right bottom corner), far from the granuloma produced by the antigen $(\mathrm{left})$. $(\mathrm{BCG} \times 100)$.

surrounded by the inflammatory infiltrate, at times distant from the brown granules of the antigens and from the granuloma produced by these antigens (Figure 6).

Blood vessels were also seen within the infiltrate, normally at the side of a nerve bundle.

\section{Discussion}

Büngeler \& Fernandez ${ }^{12}$ were the first to report the frequency of altered nerves in the granuloma of the Mitsuda reaction. Serial, ${ }^{15}$ studying 56 biopsies of lepromin reactions, encountered nerve alterations in 44 cases $(78 \%)$, described as consisting of infiltration of the epineural connective tissue, infiltration of the epineurium and partial, sometimes total, endoneuritis of some areas in the fine nerves. Desikan et al. ${ }^{7}$ described a tendency for the lymphocytes to cluster around nerve twigs in TT and BT cases, as soon as 24 hours after lepromin inoculation. In the 39 of their 77 cases in which nerves could be seen, exsudate cells were found to surround them, without actually infiltrating or destroying them.

Mistry et al., ${ }^{20}$ also in a sequential study of lepromin in 5 patients, detected no changes in most of the dermal nerves, but nevertheless found some of them to be surrounded by infiltrate. In one tuberculoid and in two borderline patients they found minimal perineural cell activity on 10th/21st post-injection days of Dharmendra lepromin. They were not able to demonstrate mycobacterial antigens in the sections on the 21 st day with BCG and PAP method.

In our study, $85 \%$ of nerves showed some degree of contact with the granuloma, or 
involvement by the granuloma. Involvement was much greater than that expected by chance, as measured by the frequency of involved nerves versus that expected (on the basis of areas of the slides having nerves and areas of the slides having inflammation). Of all nerves, only $15 \%$ were not in contact with the inflammatory infiltrate.

This makes quite likely the existence of some sort of relationship between the neural tissue and the immunological response to the lepromin, as suggested by Desikan et al. ${ }^{7}$ The absence of intraneural antigen in practically all cases and the low incidence of endoneuritis (less than $1 \%$ of all nerves) observed in our study, makes it very unlikely that the hypothesis of nerve damage in lepromin reaction was caused by a selective predilection of the inactivated bacillus and its antigens for a dermal nerve, or some 'affinity' for Schwann cells, as described in the actual disease. 5,21,27,28

On the other hand, the finding of $85 \%$ of nerves being closely related to the inflammatory infiltrate, with $30 \%$ presenting perineuritis, suggests that a relationship between the granuloma and the perineural area could exist.

Positive lepromin-like reactions have been obtained in the past by injecting normal skin extracts in humans, ${ }^{30,31}$ and also tuberculoid granulomas were demonstrated in rabbits inoculated with an extract of peripheral nerves, devoid of any mycobacterial antigen.

That lepromin-like reactions can be produced by skin and nerve extracts supports the hypothesis of some antigenic similarity between $M$. leprae and peripheral nerves, with possible cross-reactivity of antigens. This hypothetical possibility certainly needs further research for confirmation.

Ghaswala et $a l .{ }^{32}$ has demonstrated identical binding of serum antibodies in leprosy patients and in normals, to a sonicate of normal human peripheral nerves. In vitro, Benjamins et al $^{33}$ observed cross-reactivity of sera from leprosy patients between a 35$\mathrm{kDa}$ neural antigen and a synthetic analogue of the terminal dissacharide portion of phenolic glycolipid-I. Naafs et al. ${ }^{35}$ showed that anti- $M$. leprae monoclonal antibodies cross-react with dermal antigenic determinants. Some of these determinants may be associated with small nerve fibres, as was observed using MoAb F116-21, which crossreacted with the peripheral axons.

The absence of mycobacterial antigen within the nerves is strong evidence that nerve involvement in lepromin reaction is not caused by direct action of the inoculated substance. The finding of BCG-reactive deposits in one case, without producing endoneuritis, could perhaps be explained by the fact that, to be recognized and to produce local inflammation, bacterial antigen has first to be externalized by Schwann cell destruction, ${ }^{27}$ and in this particular case the stained antigen was placed inside an apparently intact Schwann cell cytoplasm. Moreover, as that particular patient was a previously multibacillary case, this antigen could be a residual of his former multibacillary period, and not the lepromin antigen.

Further studies should be done for a better understanding of the significance of the neurotrophic tendency of the granuloma in lepromin reaction, which appears to be caused not by the simple presence of the antigen in the nerves (as suggested by Serial ${ }^{15}$ ) nor by simple chance, as there is a clear preference for the infiltrate to locate around nerve structures in more than $85 \%$ of all detectable dermal nerves, even distant from the antigen deposits.

The type and intensity of the histological reaction to the Mitsuda antigen has been graded by several authors, ${ }^{3,17,29}$ mirroring the clinical spectrum of the disease. ${ }^{6,14,18}$ 
There is a general agreement that the absence of scarcity of bacilli in the sections of the positive cases is important to measure the resistance of the patient to the disease or to $M$. leprae. The higher sensitivity of BCG in demonstrating the presence of $M$. leprae or its antigens, in comparison with bacillary stainings like the Wade-Fite method, is well demonstrated in our study, as BCG-reactive deposits were found in $98 \%$ of cases, compared with only $53 \%$ of AFB detection. Therefore, the anti-BCG method could be of much more value in classifying the cases, when associated with spectral histological criteria of lepromin reaction. The clearance of the antigen in the tissue could evaluate, with more accuracy, the capability of the host to respond to mycobacterial stimulus, and thus to measure its resistance, especially in weak reactors or in clinically doubtful Mitsuda reactions.

This study reinforces the hypothesis of the existence of an antigenic link between $M$. leprae and peripheral neural tissue, ${ }^{7}$ which could explain the neurotropic tendency of the granuloma in the Mitsuda reaction and the Mitsuda-like granulomas produced experimentally with normal tissue antigens. If the possibility of an antigenic link is confirmed in the future, the positivity of lepromin reaction should be re-evaluated, as the size of the granuloma could result from a reaction to antigens other than that of $M$. leprae, thus complicating its interpretation as a measurement of the host response to $M$.leprae and, consequently, providing a theoretical basis to question its validity when used to characterize the epidemiology of leprosy.

\section{Acknowledgments}

We wish to acknowledge the contribution of Drs C. Paniago Pereira and I. M. Costa (University of Brasilia, Brazil); C. Kalil, T. Cestari and G. S. del Pino (Secretary of Health, Porto Alegre, Brazil) and M. F. R. Waters (Hospital for Tropical Diseases, London, England) who lent several blocks for this study; also that of Drs L. M. Coutinho and T. Cerski (Porto Alegre, Brazil) and Mr C. Peacock and Mrs M. Hackett for their help and technical advice in immunoperoxidase techniques. We are indebted to Drs B. Duncan and P. Gaylarde for their helpful criticism.

This investigation received a grant from Coordenação de Aperfeiçoamento de Pessoal de Ensino Superior (CAPES), Ministry of Education, Brazil.

\section{References}

${ }^{1}$ Mitsuda K. On the value of a skin reaction to a suspension of leprous nodules. Hifuka Hinyoka Zasshi (Japanese Journal of Dermatology and Urology), 1919; 19: 697-708. Reprinted in Int J Lepr, 1953; 21: 347358.

2 Azulay RD, Andrade LC, Silva C, Rabelo Neto AV, Azulay JD, Garrido Neves R, Alonso AM. Comparison of the macroscopic readings and microscopic findings of the lepromin reaction. Int J Lepr, 1960; 28: 38-43.

3 Bechelli LM, Rath de Souza P, Quagliato R. Correlação entre os resultados de leitura clinica e do exame histopatologico da reação de Mitsuda. Rev Bras Leprol, 1957; 25: 21-58.

${ }^{4}$ Garrido Neves R. Hanseniase, Contribuição aos parâmetros da classificação, Niteroi, Thesis, 1986.

5 Jopling WH \& McDougall AC. Handbook of leprosy. 4th ed. Oxford. Heinemann, 1988, 180 p.

6 Job CK, Kircheimer WF, Sanchez RM. Variable lepromin response to Mycobacterium leprae in resistant armadillos. Int J Lepr, 1983; 51: 347-353.

7 Desikan KV, Muckerjee A, Ramu G, Tiwari VD. Sequential histological study of lepromin reaction. Int J Lepr, 1983; 51: 473-480. 
${ }^{8}$ Dugan E, Modlin RL, Rea TH. An in situ immunohistological study of Mitsuda reactions. Int J Lepr, 1985; 53: 404-409.

9 Hayashi F. Mitsuda's skin reaction in leprosy. Int J Lepr, 1933; 1: 31-38.

10 Schujman S. Histopatologia de la reaccion de Mitsuda. Estudio progresivo y comparativo de las reacciones que provoca en las diversas formas de lepra. Rev Bras Leprol, 1936; 4: 469-475.

11 Alayon FL, Souza Lima L. Sobre a histologia da reação de Mitsuda em lepromatosos. Nova contribuição ao seu estudo. Rev Bras Leprol, 1940; 8: 367-374.

12 Büngeler W, Fernandez JMM. Estudo clinico e histopatólogico das reacções alérgicas na lepra. Rev Bras Leprol, 1940; 8: 157-170.

13 Andrade LMC. Comparação entre os aspectos microscópicos e macroscópicos do teste lepromínico. Bol Serv Nac Lepra, 1962; 21: 95-124.

14 Thomas J, Joseph M, Ramanujam K, Chacko CJG, Job CK. The histology of the Mitsuda reaction and its significance. Lepr Rev, 1980; 51: 329-339.

15 Serial A. Neuritis after intradermal tests with Mycobacterium leprae in patients with tuberculoid leprosy. Int $J$ Lepr, 1979; 47 (Suppl.): 426.

16 Job CK, Sanchez RM, Hunt R, Hastings RC. Prevalence and significance of positive Mitsuda reaction in the nine-banded armadillo (Dasypus novemcinctus). Int J Lepr, 1987; 55: 685-688.

17 Petri V. Histology of the Mitsuda reaction of healthy adults with no known contacts with leprosy patients. Int J Lepr, 1985; 53: 540-545.

18 Bakos L, Müller LFB, Busko MG, Peres MP, Cestari T. A histologia da reação de Mitsuda - Dado auxiliar para posicionar os tuberculoides reactionais dentro do espectro dimorfo. An Bras Dermatol, 1988; 63 (supl.1): 219-221.

19 Souza EM. Estudo comparativo das respostas da pele exposta cronicamente à luz solar e da pele não exposta à luz solar, em caucasóides não hansênicos, ao antígeno de Mitsuda, Campinas, São Paulo, Thesis, 1989.

20 Mistry NF, Birdi TJ, Uplekar M, Antia NH. A sequential histopathological study of the lepromin reaction in leprosy patients. IRCS Med Sci, 1984; 12: 287-288.

21 Iyer CGS, Desikan KV. Nerve involvement in leprosy; pathogenesis and significance. Neurology (India), 1968; 16: 89-92.

22 Fleury RN, Bacchi CE. S-100 protein and immunoperoxidase technique as an aid in the histopathologic diagnosis of leprosy. Int J Lepr, 1987; 55: 338-344.

23 Mshana RN, Humber DP, Harboe M, Belehu A. Demonstration of mycobacterial antigens in nerve biopsies from leprosy patients using peroxidase-antiperoxidase immunoenzyme technique. Clin Immunol Immunopathol, 1983; 29: 359-368.

24 Harboe M, Mshana RN, Closs O, Kronvall G, Axelsen NH. Cross reactions between mycobacteria II. Crossed immunoelectrophoretic analysis of soluble antigens of BCG and comparison with other mycobacteria. Scand J Immunol, 1979; 9: 115-124.

25 Sternberger LA, Hardy PH, Jr, Cuculis JJ, Meyer HG. The unlabelled antibody enzyme method of immunochemistry. Preparation and properties of soluble antigen-antibody complex (horseradish peroxidase) and its use in identification of spirochaetes. J Histochem Cytochem, 1970; 18: 315-333.

26 Ridley DS. La biopsia de piel en la lepra, 2.ed., Basilea, Documenta Geigy, 1983, 63 p.

27 Ridley DS. The leprosy bacillus. In: (1988) Pathogenesis of Leprosy and Related Diseases, London, Wright, 1988, $250 \mathrm{p}$.

28 Mshana RN, Belehu A, Stoner GL, Harboe M, Haregewoin A. Demonstration of mycobacterial antigens in leprosy tissues. Int J Lepr, 1982; 50: 1-10.

29 Michalany NS, Michalany J. Histopatologia da reação de Mitsuda em adultos sadios não comunicantes de hansenianos. Hansen Int, 1983; 8: 105-123.

30 Kooij R, Gerritsen Th. Positive "lepromin" reactions with suspensions of normal tissue particles. Int J Lepr, 1956; 24: 171-181.

31 Miranda RN, Grokoske LFK, Schubert WA. Lepromino-reação comparada com injeção de extrato de pele normal. Publ Cent Est Leprol, 1962; 2: 24-29.

32 Ghaswala PS, Mistry NF, Antia NH. Serum antibodies of normals and leprosy patients show equal binding to peripheral nerve. Int J Lepr, 1989; 57: 690-692.

33 Benjamins JA, Callahan RE, Runft D, Gerras G, Lefford MJ. Anti-neural antibodies in leprosy sera: further characterization of the antigens. J Neuroimmunol, 1989; 21: 125-135.

34 Hsu SM, Raine L, Fanger H. Use of avidin-biotin-peroxidase complex (ABC) in immunoperoxidase techniques. J Histochem Cytochem, 1981; 29: 577.

35 Naafs B, Kolk AHJ, Lien RAMCA, Faber WR, Van Dijk G, Kuijper S, Stolz E, Van Joost T. AntiMycobaterium leprae monoclonal antibodies cross-react with human skin; an alternative explanation for the immune responses in leprosy. J Invest Dermatol, 1990; 94: 685. 